\title{
AN INTERVIEW WITH GWEN HEAD
}

Cynthia Larson

GWEN HEAD was born in New Orleans, April 21, 1940. She attended Southern Methodist University, Trinity University, and St. Mary's University. She also pursued extensive private studies in music (piano), and spent most of 1961 and 1964 travelling in Europe.

Her first published poems appeared in Poetry Northwest in the Spring, 1967 issue, and were awarded that magazine's Helen Bullis Prize in 1968. Since then, her work has appeared in many other magazines, including Poetry Now, Prairie Schooner, The Iowa Review, Poetry, The Antioch Review, The Ohio Review, Calyx, Nimrod, Chowder Review, Concerning Poetry, Niagara, Seattle Review, Water Table, and Poetry* Texas. Her two collections of poetry, both published by the University of Pittsburgh Press, are Special Effects (1975) and The Ten Thousandth Night (1979). A chapbook, Hannah's Quilt, was published by Chowder Chapbooks in 1982. Poems by Gwen Head are included in several anthologies, among them A Geography of Poets, edited by Edward Field (Bantam Books, 1979), Iron Country (Copper Canyon Press, 1979), and the Owl Creek Press anthology of Northwest poets.

In 1975 Gwen Head was named Anne Sexton Fellow at the Bread Loaf Writers' Conference. In 1978 she taught at the Aspen Writers' Conference and won the Helen Bullis Prize for the second time. In 1980-81 she was a Visiting Lecturer at the University of Iowa Writers' Workshop. While in Iowa she was a co-editor of a special double issue of The Iowa Review devoted to contemporary American women writers, which was also published in book form by Macmillan in 1982, under the title Extended Outlooks. She is currently working on new poems and a collection of short stories. One of her stories, "Substantial Risk," won the Aspen Anthology 1979 Fiction Prize. She is also Editor-Publisher of Dragon Gate, Inc., a poetry press.

LARSON: You spent a busy 1980-1981 academic year as a Visiting Lecturer with the University of Iowa's Writers' Workshop. Not only did you teach workshops and forms classes, but you also became involved in editing a womens' anthology of poetry and fiction, were hard at work on what will be your third book of poems, and gave poetry readings, gracing the stage 
of the last reading with some lovely quilts from your collection (more on that later). Could you share some of your reflections on that year spent with us?

HEAD: My afterthoughts on Iowa follow what I suppose must be a normal pattern of retrospection. Daily life, at least my daily life, tends to be so jumbled; everything that happens seems so close-up and urgent that it's hard to discern any pattern or sort out the quality of one's experience. Highs and lows, peaks and valleys, are apparent only in retrospect. Looking back on my year at Iowa, I see that the peaks were higher than I thought. I've been rereading some of the student work I dealt with, and much of it is fine: varied, original, full of energy. Teaching good students confers several sorts of blessings: it sharpens the critical faculty (assuming one exists in the first place!), compels one to read more, and more seriously, in greater depth, on a wider range of subjects. It competes, in at least two ways, with one's own work. And as long as that work still gets done, the demands of teaching are healthy, and the companionship and the feeling of being part of an ongoing devotion to writing can be deeply satisfying. Another peak or long ridge was my work, with Jane Cooper, Marcia Southwick, and Dee Morris, on the women writers' issue of The Iowa Review that Macmillan published under the title of Extended Outlooks.

The valleys? It was a difficult year from a practical standpoint. I'm a very deeply rooted Washingtonian, after living in the area for seventeen years. Moving myself, my daughter, my books, my writing and press files, proved to be a lot more difficult and time-consuming than I expected. And there were times when I got tired of a steady diet of poetry and talk about poetry. In Seattle, I hang out with a mixed gang of architects, musicians, artists, small press people, craftsmen, restaurateurs, shopowners ... I'd have liked the leisure to back off a little from the Workshop, talk to people in other fields. But that problem was mostly a function of my crazy schedule. Undoubtedly, too, I was less efficient, as a novice teacher, than I could have been, or perhaps will be later. But I'm not really convinced that "efficiency" is a proper criterion to apply to work that means so much to its authors, and ultimately to others as well. In all, it was a good, tough year. Reverting to the scenic analogy: I feel I got someplace (even though I'm not sure where, yet), and saw a lot on the way.

LARSON: A part of my recalling you to your stay in Iowa City concerns eliciting your reactions to Peter Stitt's statement in The Georgia Review (Fall, 1981) on the "academic style of our age." Mr. Stitt describes this style as "sonorous, serious, and instructive" in tone, and "highly accomplished, effortlessly, smoothly urbane" in technique. Poetry of this type, Mr. Stitt continues, is written mostly by professors who are "graduates of the best creative writing programs in the country, chiefly conducted by Donald Justice and others at the University of Iowa." Since you are included in that brief phrase "and others at the University of Iowa," I'm wondering what your thoughts are on Peter Stitt's comments. 
HEAD: I can certainly see how Peter Stitt's remarks might have raised a few hackles at Iowa. However I think that his comments have to be considered in the much larger context of the article as a whole, which is in fact a very extensive review of what he considered the most interesting volumes selected in the first two years of the National Poetry Series competitions. I think, and Stitt clearly thinks too, that the word "competition" should be in quotation marks as regards those volumes chosen by individual judges. He may perhaps be right in claiming a certain blandness and orthodoxy about some, not all, of the selections. However I am not convinced that the blame for that relative sameness of style, if in fact it exists, should be laid at the door of any writing program or programs, particularly the University of Iowa. I have already said that I considered the work of my students to be unusually diverse and interesting and personal. If there is an orthodoxy, a set of assumed critical norms or even received ideas, about the National Poetry Series, it's probably inherent in the very concept. I think it's worth pointing out that in addition to the enormous Michener grant, several other high-powered foundations were involved in funding the National Poetry Series. Foundations, especially major foundations, tend to be wellsprings of orthodoxy in spite of themselves. It's as if it's the nature of a major foundation to confer a kind of intellectual sanctity. I think that's a real risk in the foundation game. I note further that the publishers who actually produce the selected manuscripts are all impeccably solid, large, well-known, major New York houses. Stitt himself uses the phrase "noblesse oblige" to describe the whole undertaking. I think it's apt. It is also worth mentioning the impeccably blue-chip list of judges: Donald Hall, Donald Justice, Philip Levine, Mike Harper, Louise Glück, Stanley Kunitz, Carolyn Kizer, among others. These are all wonderful poets, and I think it's particularly unfair for the Workshop, because of Justice's long association with it, to be singled out as a target for Peter Stitt's charges about a dominant "establishment" poetic style in this country. But I also think that it's possible to imagine an equally distinguished list of judges that might have produced more diverse-not necessarily more adventurous-choices. So I guess my final conclusion is that Stitt's comments have to be taken in context. What he is really writing about is not the University of Iowa's Writers' Workshop but the National Poetry Series.

LARSON: Later in his review essay, Mr. Stitt notes that the "academic style of any given age is the safe style, the acceptable style-if you will, the careerist style." Whatever Mr. Stitt intended by his term a "safe style," I certainly wouldn't think it applies to your poetry. One of the things that impresses me about your poetry is the integrity with which you search out the form and language that would best convey each poem's emotions, images, and ideas, as well as the range of forms and voices you have at your command. I'm thinking of poems as different from one another as "Wreck" 
(with its evocative series of diverse yet related "convergences'), "Midas," and "Facts of Life," though I certainly don't want to restrict your responses to these specific poems.

HEAD: It's very important to me, sometimes to the point of a near-paralysis that can last for years, to find what seems to me exactly the right form or voice for each poem that I write. Often, in fact, the poem only comes when I have found what I can see to be the correct, which for me means emotionally correct, formal solution. "Wreck" is certainly one example. I had been pondering the subject of the poem for two or three years, and all that time I had assumed that it ultimately would be a specimen of what I think of as binary narrative, in which two narrative lines are fused or contrasted or allowed to collide. In fact, I think they do all three at various points in the poem. But the material was very personal and I wasn't satisfied with any of my attempts to deal with it. The poem as it stands finally got written when one day, and this was during the fall semester when I taught at Iowa, a third voice suddenly announced itself in my head. It was the voice of the foreign car mechanic and restorer, an arrogant, rather officious, slightly bullying voice, with a fine vernacular swing that neither of the other two had: "Whatever you do, it's going to cost you plenty." His narrative line was the first of the three to be written; after that I went back and wrote the other two to fit into the implicit spaces between each of the fifteen lines of the mechanic's narrative. The fact that his voice spoke exactly fifteen lines was a happy accident itself, because it meant that to be fully contained and framed by the mechanic's narrative, the other two voices had to speak only fourteen lines each. One direct result of that, although no one has ever noticed it until I've told them, is that the third strand, the interior monologue of the woman who is about to wreck her marriage, to announce the end of it, the strand that is printed in italics to further distinguish it from the rest, could be written as a very free sonnet, and it was fun to sneak that in. Another delightful part of solving the formal problems of this particular poem was trying to determine the most effective way to present it graphically on the page. I initially assumed that each of the three narrative lines would simply be indented slightly more, and that I would therefore have a series of three-line stanzas. But when I looked at it on paper that wasn't very impressive. So I tried it again with the two narrative lines I'd known from the beginning I would write, those of the estranged wife and the friend who experiences the almost telegraphic communication of her misery, paired together, and the mechanic's narrative, which is set out all the way to the margin, used to frame the indented couplets of the other two narratives. That seemed to be the right solution; and setting off the wife's narrative further by putting it in italics to represent the fact that it is an interior monologue (in addition to its sonnet form) seemed to me to further disentangle, and thereby strengthen the three separate lines. 
LARSON: It seems that much of your poetry concerns those inevitable experiences that alter the way we view and order our worlds. The transition from innocence to experience, for example, is perhaps implicit in "A Nest in the Wind" with its line from Portrait of a Lady, and explicit in the epiphany in "The Hawk in the Garden," which ends "Dazed / I began to / see the most innocent garden as a maze; / at its heart, dark stain / and unhealable schism." In other poems there's a wonderful tension that develops between the realization in, say, "Upheaval" that the "face in the mirror was a mortal face" and Edith's hunger in the lines "No window / can ever open wide enough. I want / the limitless spaces." (From "Edith Cast Down.") And then in other poems you seem to suggest that one solution to the problems life offers, problems like the one confronting the speaker in "The Woman in the Middle," is art and the imagination. I'm thinking of the "Sweet Amaryllis" remaking itself out of memory and the oneness achieved at the conclusion of "At the Piano." I guess that's one reason I like the poems "A Little Elegy" and "The Ten Thousandth Night" so much. You seem to be indicating that life is what we make it: "What you see may be either, neither, or both, depending / on how unquiet is your point of view" ... even though "it has always been the same story / and always it ends in death."

HEAD: I think in all of these questions you are getting at the same fundamental point about my work: that I try to preserve some sense of the emotional complexity of experience as it happens. As a writer, at least, I have a very contradictory temperament, and I like it that way, I think it's a source of potential strength. I dislike the imposition of terms, but I think I'm both a skeptic and a romantic. I try when I write to preserve the energy of that conflict. You speak of both "A Nest in the Wind" and "The Hawk in the Garden" as dealing with the transition from innocence to experience. That's true in a way, but it's perhaps more accurate to speak not of the transition between innocence and experience but of an oscillation between the two states. That was part of what I was trying to imply at the end of "The Hawk in the Garden" with the phrase "unhealable schism." Of course that poem also ended that way because I was painted into a corner by my intricate rhyme scheme. "A Nest in the Wind" is a very brief poem, but there are other conflicts or at least contrasts in it, which the two italicized quotations from The Portrait of a Lady and the other from a popular magazine on the interpretation of dreams are intended to suggest. The point is that beyond the difference in material and psychological circumstances between the two implied characters in the poem, there is the same recurrent irrational, but invincible romantic yearning. But I would hope it's not without an edge of irony and humor even in this very small and now excessively glossed poem. I find that I haven't a great deal to say about the last line of "Upheaval" except that it now seems too pat and rigidly iambic. Perhaps because my own life has been going through an expansive phase I feel much closer to 
the ending of "Edith Cast Down." I do want "the limitless spaces." But my poem is about Edith Wharton's imagined death, so perhaps there's no end to the vital impulses and longings that propel us, precisely, towards death. And of course art and imagination offer one way to grapple with what we can never grasp-to contend with the complexities of our lives. The wish to find inherent patterns in experience, to be able to abstract those patterns, render them into formal structures that can be apprehended from angles impossible in the original state of the experience, seems to me a fundamental human need. "Salvation" isn't the kind of word I can use with a straight face, but I do think it's fair to speak of the power of art to reconcile individuals with aspects, at least, of their own lives. I keep talking about structures, about imaginary models, but these structures have to be both strong and flexible to contain a normal variety of experience, and above all they have to have lots of emergency exits. Not only life but art, so-called, is what we make it; these imaginary structures have to remain somewhat open and ambiguous. If they are too tight, too closed, too rigid, if they can't stand the repeated shock and tremors of the experience they are meant to contain, then they're no good. And of course the idea of the structure itself is highly suspect. One reason why I've come increasingly to enjoy writing in strict forms is that they're such fun to work against. I don't think one can be a serious poet without being a little playful too. It's important that the artist subvert his own structure, at least a little bit. The sandcastle can have as many turrets and crenelations as it wants, but it should always be placed within reach of the waves.

LARSON: In your interview with Karla Hammond (Nimrod, Fall/Winter 1980) you discussed the important influence your musical background had on the poetry in Special Effects. Would you say that influence continues to be felt in your recent work?

HEAD: Questions about musical influences make me a bit uneasy. The first reason is that I've already covered that ground with perhaps excessive thoroughness in the Nimrod/Karla Hammond interview you mention. But the second reason is more important, and it is that I guess I no longer feel much like a musician. In the last few years, a powerful emerging interest in publishing has insidiously forced me to do something I never thought I'd manage: I've cut down on what has always been an unwieldy range of interests and activities, and the ones that remain tend to be centered upon, or attached to, writing or publishing. "Forced" is the wrong word, for it's been a matter of simple daily preference; the press, like a new baby, is a "terrible joy," and for the time being, second only to my own work and my daughter's welfare, I'd rather devote myself to it than to anything else I can think of. Playing the piano even moderately well takes two or three hours of practice most days, and reading and commenting on manuscripts, plus a greatly enlarged correspondence, take up at least that much time. I think, 
too, that having stated in several poems the importance of music in my early life and its influence on my eventual development as a writer, I no longer feel much need to (forgive me) harp on that particular theme. Maybe the real answer is just that I'm stale on music, temporarily, I trust.

LARSON: In this same interview, you said in response to a question on the difficulties of being a writer and a wife and mother: "Women are trained from infancy not to act but to react, and it's very difficult to accept the responsibility for controlling your own life and using your own talents regardless of whom you choose to spend that life with." I'm interested in this difference between a woman's acting and reacting as you use it in your short story "Substantial Risk." The lawyer-husband continually accuses his wife of just reacting, of not being in control. Yet the wife, through her empathetic reacting to the situation in which she finds herself, is really the only one who even begins to understand what happened. Moreover, she experiences one of those shifts in perspective: "But it came over me there in the parking lot that the order of our life, its shining space and proportion, depends on what is left out ...we are all arbitrary, conventional in the full sense. Call us, collectively, a truth of omission. We exist by the grace ofwhat? A gap, a lapse, a momentary forgetfulness in the black mind of the universe." In this story, the wife's action is only evident in her interior monologues, in her giving conscious form to her experience through language. But since the wife's action remains internal, the husband never even suspects that it's there. I'm also interested in how you end the story.

HEAD: I think you're right that the wife in "Substantial Risk" is exactly the sort of reacting, traditionally "feminine" woman that I had in mind in my comments in the Hammond interview. She seems to be a very trammeled, conventional person, perhaps overly fond of the apparent luxury of her life. And of course at the end she does go back to her judgmental husband, to the situation in which her own interior complexity is neither recognized nor valued. But I don't think of her as a defeated character because she has had some understanding of her own situation. She has had, indeed, a few moments of revelation in which she has come into contact with madness in its extreme form and revelled in it, embraced it, communed with it, recognized in the black madwoman an external manifestation of what may be her own soul. If the story has a point it's precisely this affection, this communion, this recognition of her own craziness, its kinship with the craziness of her potential assailant, even her potential murderer, although the murder does not in fact take place. The black crazy lady is an extreme manifestation or personification of the idea of risk. But I think what I wanted to say is that we not only have to meet risks, but embrace them, cherish them if we're to continue really living, at least in our own minds and spirits.

LARSON: I'm very moved by the title poem in your chapbook Hannah's Quilt. 
As I was rereading the poem, I thought of Vladimir Nabokov's statement that "this capacity to wonder at trifles-no matter the imminent perilthese asides of the spirit, these footnotes in the volume of life are the highest form of consciousness ..." and Joseph Brodsky's observation that "if there is any substitute for love, it's memory."2 This impulse not only to wonder at and remember details from one's life but also to record them in some more permanent fashion is behind many kinds of autobiographical statements. A quilt becomes a perfect metaphor for autobiographical impulses since a quilt-maker literally transforms the cast-off fragments that once surrounded her life-those torn dresses and curtains, old aprons and stillgood jacket linings-into a self-designed and, one hopes, internally coherent work of art.

HEAD: You're very generous, in speaking about the poem, to quote Nabokov and Brodsky's comments. And yes, I would say that if the poem has any definable purpose, it is to praise the feminine, indeed the human, impulse not only to salvage but to cherish and sustain. When I acquired this quilt during my first visit to Iowa City in February 1980, when I was invited to read with Carol Muske, I knew that I had to write a poem about it. Of course I was quite busy during that brief stay in Iowa City, but in the few solitary hours that I had to spend in my room in the Iowa House I found myself unfolding Hannah's quilt again and again and sitting on the floor with it, tracing patterns, studying details, smelling its peculiarly antique and nostalgic smell, feeling intensely involved with it. If it's possible to fall in love with an object or artifact, then I was and still am in love with this particular piece. It's not accurate even to call Hannah's quilt a collector's item, a "piece," or a static work of art. For me it isn't. It's something that happened to me, that keeps happening every time I look at it. But there was such richness of detail, such an enormous sense of a whole personal history compressed into this amazingly concise and beautiful form, that organizing the things that I kept noticing about it into any sort of coherent sequence was extremely difficult. Finally I did something I rarely do with a poem, but often do when I'm trying to write a short story. I sat down and made notes and ordered them into a sort of implied narrative sequence, and then I was able not only to begin but to finish the poem.

LARSON: Is there any question that you've always hoped an interviewer would ask you and that, so far, none has?

HEAD: I think that I would like to talk about the joys of editing. In a way, this question relates back to your inquiry about the present status of my interest in music. I think editing is one of the things that has supplanted an active interest in the performance of music. I've indicated in another interview that one of the things that was most valuable to me in my musical education was being taught to read the score of a composition really closely, 
really accurately. I think this kind of attention has carried over, I hope to advantage, in my own writing. I feel that it's one of the major things that I have to offer as a teacher. It's very difficult to get outside your own work, read it as a stranger coming fresh to the printed page would read it, see whether the punctuation is really faithful to the verbal music of the poem. Editing provides a fine escape from the claustrophobic egotism of one's own work. It's also a splendid outlet for stored-up compulsiveness. It makes me feel I can be relaxed and sloppy about almost anything else. Other rewards include fascinating correspondence with the writers I publish and with quite a few that I don't publish. Editing is also a great vantage point from which to survey the language as a changing and developing organism. There have been significant changes in spelling, punctuation, many points of usage within my lifetime. And then there are a host of small delights: the occasional discovery of a new word like "actinic" in John Woods's manuscript, or "carphology" in Linda Gregerson's, or the trivial but delightful fact that an ebbet is "a small common green newt." But that's not what Ebbets Field is named for. It's named after a man named Ebbets who was an early baseball commissioner, as no doubt everyone but me knew already.

Notes

1 Vladimir Nabokov from "The Art of Literature and Commonsense" in Lectures on Literature.

2 Joseph Brodsky from "Nadezhda Mandelstam (1899-1980)," New York Review of Books (Vol. XXVIII, No. 5). The poems "Wreck" and "Hannah's Quilt" are included in the chapbook Hannah's Quilt which was published by Chowder Chapbooks in 1982. 
